\title{
The role of iron oxidizing bacteria to the quality of leachate on acid sulphate soil
}

\author{
Khairatun Napisah ${ }^{1 *}$, Azwar Maas², Sri Nuryani Hidayah Utami², and Wahida Annisa Yusuf ${ }^{3}$ \\ ${ }^{1}$ Assessment Institute for Agricultural Technology of South Kalimantan \\ ${ }^{2}$ Department of Soil Science, Faculty of Agriculture, Universitas Gadjah Mada \\ JIn. Flora no. 1, Bulaksumur, Sleman, Yogyakarta 55281, Indonesia \\ ${ }^{3}$ Indonesian Swampland Agricultural Research Institute (ISARI) Banjarbaru \\ *Corresponding author: khairatun.napisah@yahoo.co.id
}

Received: $14^{\text {th }}$ April 2018; Revised: $16^{\text {th }}$ December 2019; Accepted: $11^{\text {th }}$ February 2020

\section{Keywords:}

Eleocharis dulcis, Eleocharis retroflaxa, pyrite, Thiobacillus ferrooxidans

\begin{abstract}
The problem encountered in acid sulphate soil is the presence of pyrite $\left(\mathrm{FeS}_{2}\right)$ which causes soil to have highly acid reaction when the pyrite is oxidized. The decline in quality not only occurs on the soil but also on the quality of the surrounding waters. One way to improve the quality of the leachate is by draining it through biofilter plants in the form of purun tikus (Eleocharis dulcis) and bulu babi (Eleocharis retroflaxa) which can absorb or neutralize these elements. The purpose of this research was to know the inoculant influence of iron oxidizing bacteria to leachate quality in acid sulphate soil. The research was conducted on a pot scale in greenhouse. The research was in randomized complete block design (RCBD) of three factors with three replications. The first factor was inoculants, the second factor was water management, and the third one was phytoremediation material (E. dulcis and E. retroflaxa). The results showed that the plant height in the inoculant treatment+wood charcoal was in the range of $89.33-95.33 \mathrm{~cm}$, while that in the inoculant treatment+husk charcoal was in the range of $89.50-93.00 \mathrm{~cm}$. Meanwhile, the yield of rice with bacteria oxidizing iron inoculant+wood charcoal was higher, which was at 6.77 ton.ha ${ }^{-1}$ than inoculant treatment of oxidizing iron+husk charcoal which was only 5.95 ton.ha' ${ }^{-1}$.
\end{abstract}

\section{INTRODUCTION}

The utilization of sub optimal lands such as tidal swampland is one of the resolutions to increase the national rice production system capacity to support food self-sufficiency program. Swampland is spread over Indonesia with an area of about 34 million consisting of 20,707 million hectares of tidal swampland and 13,296 million hectares of swampland (Balai Penelitian dan Pengembangan Pertanian, 2013).

The main problem of acid sulphate soil are soil physic and chemical properties (Pusparani, 2018). Tidal acid sulphate swamp land is a sub optimum land that needs special handling because the main problem of land is less support for plant growth such as pyrite mineral $\left(\mathrm{FeS}_{2}\right)$, low pH soil, iron toxicity, and poor nutrients. The pyrite $\left(\mathrm{FeS}_{2}\right)$ which is widely contained in acid sulphate soils is stable if in reductive condition, but if in drainage the pyrite will be oxidized causing the formation of $\mathrm{H}_{2} \mathrm{SO}_{4}$ compound which can increase soil acidity (Susilawati and Fahmi, 2013).

Quality of water in sulphate land is classified in low level, indicated by $\mathrm{pH}$ of $<3.5$ and presence of soluble ions such as $\mathrm{Fe}, \mathrm{Al}$ and $\mathrm{SO}_{4}$ in toxic level (Asikin and Thamrin, 2012). Oxidation of pyrite in acid sulphate soil produces $\mathrm{H}^{+}$and $\mathrm{SO}_{4}{ }^{2}$, due to the solubility of toxic elements such as $\mathrm{Al}$, and $\mathrm{Fe}$. In the inundated conditions, Fe metal can be lost from the soil solution in several ways, among others by precipitation, being absorbed on the clay surface or $\mathrm{Fe}^{3+}$ oxide, being oxidized to $\mathrm{Fe}^{3+}$ and being carried along the water drainage (Napisah, 2019). The quality of the 
contaminated water can be improved by draining it through biofilter plants in the form of purun tikus (E. dulcis) and bulu babi (E. retroflaxa) which can absorb or neutralize these ions. According to Jumberi et al. (2004), purun tikus plant ecologically act as biofilter that can neutralize toxic elements and acidity on acid sulphate by absorbing Fe of 1.559 ppm and $\mathrm{SO}_{4}$ of 13.68 ppm. Alia et al. (2013) reported that the water plant in association with microorganisms transforms harmful pollutants become less and harmless. The roots of aquatic plants provide space for microorganisms to grow on stems and plant roots (Lu et al., 2015). Based on the research results conducted by Nurseha and Djajakirana (2004), the iron oxidizing bacteria is Thiobacillus ferroxidans. T. ferrooxidans is a bacterium that acts as iron oxidase which can metabolize metal ions, such as ferrous iron. T. ferrooxidans can grow on soil that undergoes oxidation or reduction. Through the reaction of microorganisms to oxygen, it shows that the bacterium T. ferrooxidans is microaerophilic (obligate aerobic organisms that remain well developed in low oxygen content). T. ferrooxidans are able to oxidize $\mathrm{Fe}^{2+}$ to $\mathrm{Fe}^{3+}$ and oxidize reduced sulfur compounds and utilize these oxidants as energy sources (Mariana et al., 2012). The aim of this research was to know the effect of formula inoculant to improve the quality of waste water in acid sulphate soil.

\section{MATERIALS AND METHODS}

The research was conducted on pot scale placed in the greenhouse and laboratory of Indonesian Swampland Agricultural Research Institute (ISARI) in Banjarbaru, South Kalimantan from July to November 2017. The design used in this research was a factorial

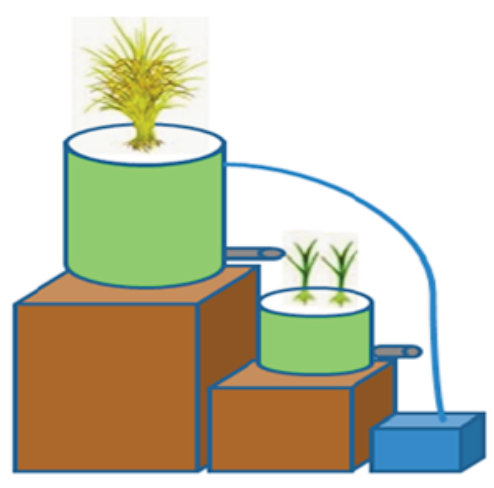

No leached (close system)

Figure 1. Pot experiment illustration

randomized complete block design (RCBD) of 3 factors with 3 replications. The first factor of inoculant $(T)$ with various inoculant formulas of: $\mathrm{T} 1=$ no formulation, $\mathrm{T} 2$ = wood charcoal, $\mathrm{T} 3=$ husk charcoal husk, $\mathrm{T} 4$ = bacteria oxidizing iron inoculant+wood charcoal, and $\mathrm{T} 5$ = bacteria oxidizing iron Inoculant+husk charcoal. The second factor was water management (P) comprising: $\mathrm{P} 1$ = no leached (closed system), P2 = leached (open system). The third factor was phytoremediation material $(A)$ that was: $A 1=$ Purun tikus (E. dulcis) and $\mathrm{A} 2=$ Bulu babi (E. retroflaxa).

Without the drying process, the sample of sulfuric acid soil was taken from the field at the selected site. It was put into a pot of $12 \mathrm{~kg}$ and then limed according to the optimum dose. After being incubated for $2 \times 24$ hours, it was continued with the planting of rice seedlings of superior varieties of Inpara 2 swamp rice taking up to 25 days with 2 clumps per pot. Basal fertilizers were given for all treatments according to recommended doses in tidal land. Recommended dose for basal urea fertilizer was SP-36: KCl with: 200 kg.ha-1: 100 kg.ha-1: 100 kg.ha-1. Selected Purun tikus (E. dulcis) and Bulu Babi (E. retroflaxa) (the same age and performance) were planted in the gutter with the same plant population for all the sewers which were stimulated in a greenhouse. The first factor of inoculant formula with carrier and with no carrier was applied to plant phytoremediation material (Figure 1). Leachate water coming from rice plant was contained in pots treated with aquatic plants as phytoremediation materials. After being inoculated by two formulas and incubated for one month, the rice crops were maintained until harvest. Observation was made on the result of dried grain yield of harvest $\left(\right.$ ton. $\mathrm{ha}^{-1}$ ) and leachate water quality including $\mathrm{pH}$,

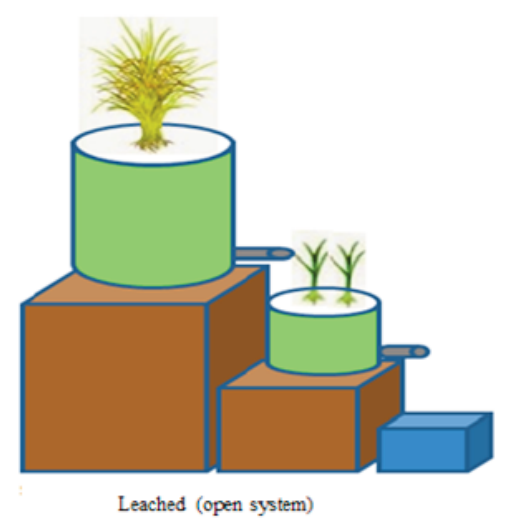


Eh, TDS, Fe, and $\mathrm{SO}_{4}$ (Balai Penelitian Tanah, 2012). The data analysis was conducted to determine the effect of treatment whether there was a significant difference in the level of the factor (variety) conducted using Duncan Multiple range Test (DMRT, $\alpha=5 \%$ ). All statistical tests were performed with SAS 9.1.3 version for windows.

\section{RESULTS AND DISCUSSION}

\section{Characteristics of acid sulphate soil}

According to soil classification, sulfidic rate (pyrite) is the characteristic of acid sulphate soil. The result showed that the soil included in the Typic Sulfaquent subgroup was observed from the $\mathrm{pH}$ value of the soil which was 4.16 (very acid) with organic soil C content of $3.699 \%$ (high) and $\mathrm{N}$ content of total land of $0.248 \%$ (medium). For $\mathrm{P}$ content, the available soil was $10.596 \mathrm{cmol}^{\mathrm{kg}}{ }^{-1}$ (low) with K-dd $0.352 \mathrm{cmol} \mathrm{kg}^{-1}$ (medium) and Al-dd $9.774 \mathrm{cmol}^{.} \mathrm{kg}^{-1}$ (high) (Table 1).

\section{Quality of leachate water in acid sulphate soil}

\section{Leachate water $\mathrm{pH}$}

Water quality in acid sulphate soil is influenced by soil biogeochemical processes. The data showed that the $\mathrm{pH}$ of leachate water continued to increase during plant growth up to 12 WAP (Figure 2). An increase in the $\mathrm{pH}$ of leachate water was followed by a decrease in the Eh value from 8 wap to 12 WAP (Figure 3). At the same time, the TDS value continued to decrease to 8 WAP and increased again in 10 WAP to 12 WAP (Figure 4).

From Figure 2 it is presented that the $\mathrm{pH}$ of leachate water in the inoculant treatment of iron oxidizing bacteria+husk charcoal carrier which was 5.16 was higher than the inoculant treatment of iron oxidizing bacteria+wood charcoal which was only 5.02. This is in accordance with the research results by Hazra and Widyati (2007) stating that inoculant of iron oxidizing bacteria can grow well on husk charcoal media. This is related to the conditions of husk charcoal which are dominated by the aromatic carbon structure making it stable and highly resistant to chemical and biological degradation in the soil. The increase of $\mathrm{pH}$ due to the treatment of husk charcoal and inoculant occurs through several mechanisms, including (1) $\mathrm{OH}$ release in the oxidation process of organic acid anion, (2) proton consumption during decarbosylation of organic acid anion, (3) $\mathrm{OH}$ ion release during organic $\mathrm{N}$ mineralization, (4) $\mathrm{OH}$ release as the effect of specific absorption of the humic material and/or organic molecules into the $\mathrm{Al}$ and Fe hydroxides, and (5) an increase in the $\mathrm{Ca}$, $\mathrm{Mg}$ and base cation $\mathrm{K}$ content of the added organic fertilizer (Haynes and Mokotobate, 2001). T. ferroxidans bacteria are able to use organic carbon in a limited way (Bacelor and Johnson, 1999). According to Mariana et al. (2012) changes in soil acidity (pH) are also strongly determined by the activity of iron oxidizing bacteria in acid sulphate soils.

\section{Leachate Water Redox Potential (Eh)}

It can be seen in Figure 3 that Eh of leachate water at the observation in 6 WAP has increased. The increase of redox potential at the beginning of the observation was due to the $\mathrm{Fe}^{2+}$ oxidation process to $\mathrm{Fe}^{3+}$ with the help of T. ferroxidans bacteria causing soil conditions to become oxidative so that the redox potential got increased. On the other hand, at the observation in 8 to 12 WAP, there was a decrease in the Eh value of leachate water. Redox potential (Eh) also had an ecological significance with respect to its effect on the balance of nutrient availability and Fe toxicity.

Table 1. The initial of chemical propert of acid sulfat soil

\begin{tabular}{lcc}
\hline Characteristics & Sulphate Acid Soil & Criteria* \\
\hline $\mathrm{pH}\left(\mathrm{H}_{2} \mathrm{O}\right)$ & 4.16 & Very acid \\
Organic $\mathrm{C}(\%)$ & 3.699 & High \\
Total N (\%) & 0.248 & Medium \\
Available P $\left(\mathrm{c} \mathrm{mol} . \mathrm{kg}^{-1}\right)$ & 10.596 & Low \\
K-dd (c mol. $\left.\mathrm{kg}^{-1}\right)$ & 0.352 & Medium \\
Al-dd $(\mathrm{c} \mathrm{mol.kg})$ & 9.774 & High \\
Fe $\left(\mathrm{mg}^{-1} \mathrm{~kg}^{-1}\right)$ & 269.997 & High \\
\hline
\end{tabular}

Remarks: $(*)$ LPT Bogor (2005) 


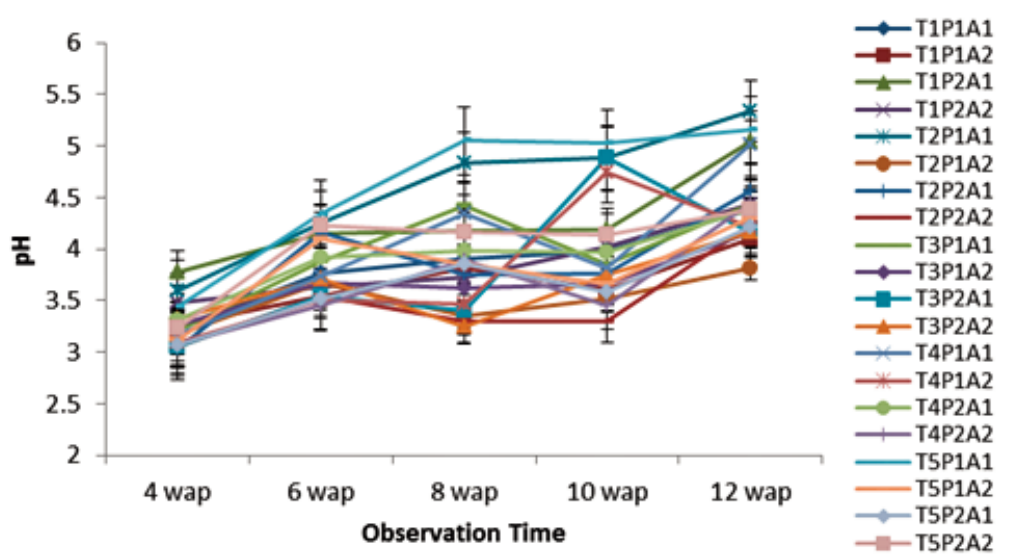

Remarks: T: Inoculant formula. (T1 : formulation, T2 : wood charcoal carrier material, T3: Husk charcoal material, T4: Inoculant of iron oxidizing bacteria + wood charcoal, and T5: Inoculant of iron oxidizing bacteria + husk charcoal). P : Water management ( P1: Closed system, P2: Opened system). A: Phytoremediation materials ( A1: E. dulcis, A2: E. retroflaxa). WAP: Weeks After Planting.

Figure 2. The dynamics of $\mathrm{pH}$ change in leachate water with the treatment of inoculant formulas, water management and phytoremediation materials
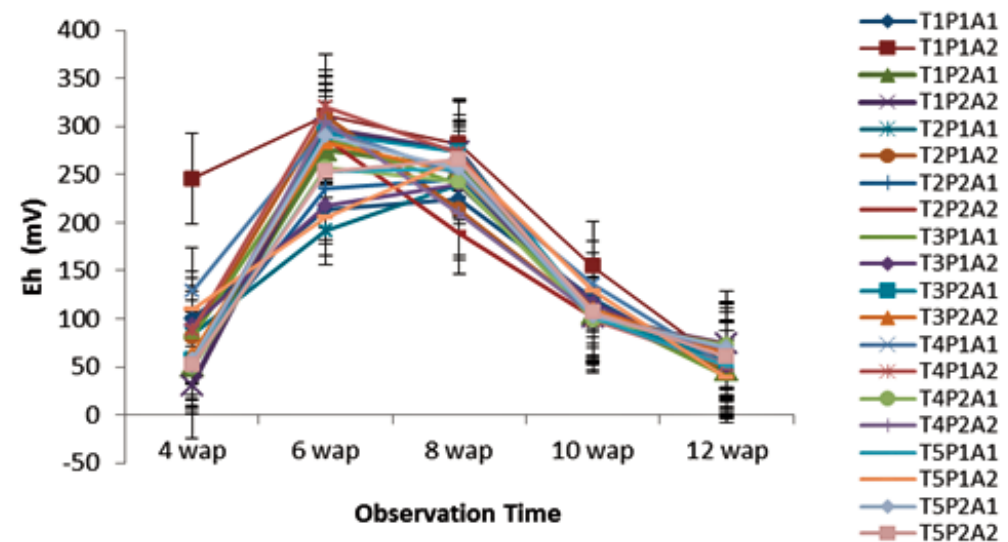

Remarks: T: Inoculant formula. (T1: Formulation, T2: Wood charcoal carrier material, T3: Husk charcoal material, T4 : Inoculant of iron oxidizing bacteria + wood charcoal, and T5: Inoculant of iron oxidizing bacteria + husk charcoal). P: Water management (P1: Closed system, P2: Opened system). A: Phytoremediation Materials (A1: E. dulcis, A2: E. retroflaxa). WAP: Weeks After Planting.

Figure 3. Changes Eh periodic leachate water with treatment of inoculant formulas, water management and phytoremediation materials

Fe is only available to plants in the reduced form $\mathrm{Fe}^{2+}$ and $\mathrm{Mn}^{2+}$ (Notohadiprawiro, 2000). Becker and Ash (2005) reported that the microbial reduction process led to the change of insoluble iron $\left(\mathrm{Fe}^{3+}\right)$ to soluble iron $\left(\mathrm{Fe}^{2+}\right)$. The decrease of Eh resulted in increased supply of $\mathrm{N}, \mathrm{P}, \mathrm{K}, \mathrm{Fe}, \mathrm{Mn}, \mathrm{Mo}$, and $\mathrm{Si}$ (Ponnamperuma, 1978). The Eh of leachate water in the inoculant treatment of iron oxidizing bacteria with higher wood charcoal was $72.1 \mathrm{mV}$ compared to inoculant treatment of iron oxidizing bacteria with husk charcoal which was only $69.5 \mathrm{mV}$. Fluctuations of Eh will also affect the ionic composition including Fe elements and other mineral elements associated with oxidation and sulfur reduction (Su et al., 2017).

\section{TDS of leachate water}

In Figure 4 it is seen that the value of Total Dissolve Solid of liquefied water at the observation in 6 to 8 WAP decreased. This was because purun tikus and bulu babi took solid elements dissolved around them for growth. Entering the observation of 10 to 12 WAP, the value of liquefied TDS in the 


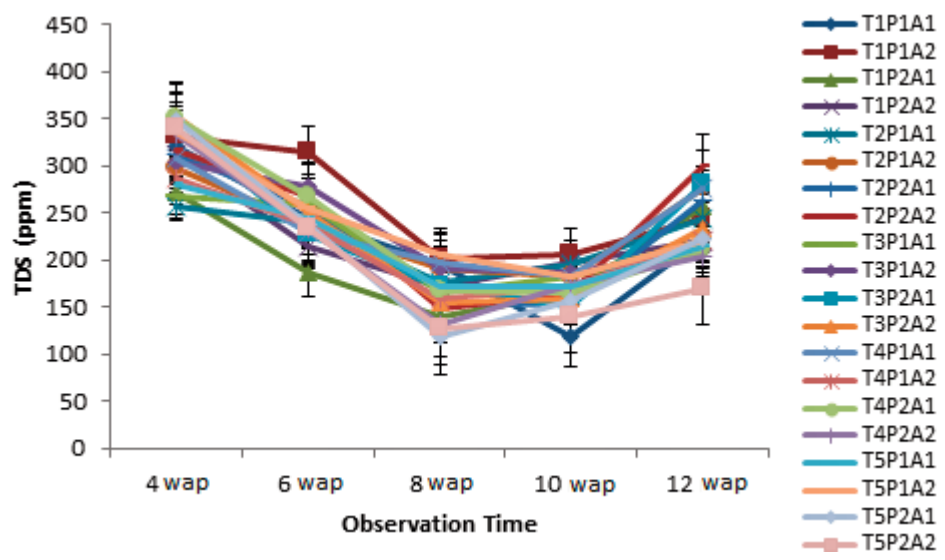

Remarks: T: Inoculant formula. (T1: formulation, T2: wood charcoal carrier material, T3: husk charcoal material, T4: Inoculant of iron oxidizing bacteria + wood charcoal, and T5: Inoculant of iron oxidizing bacteria + husk charcoal). P: Water management (P1 : closed system, P2 : opened system). A: Phytoremediation Materials (A1: E. dulcis, A2: E. retroflaxa).

Figure 4. Changes of TDS periodic leachate water with treatment of inoculant formulas, water management, and phytoremediation materials

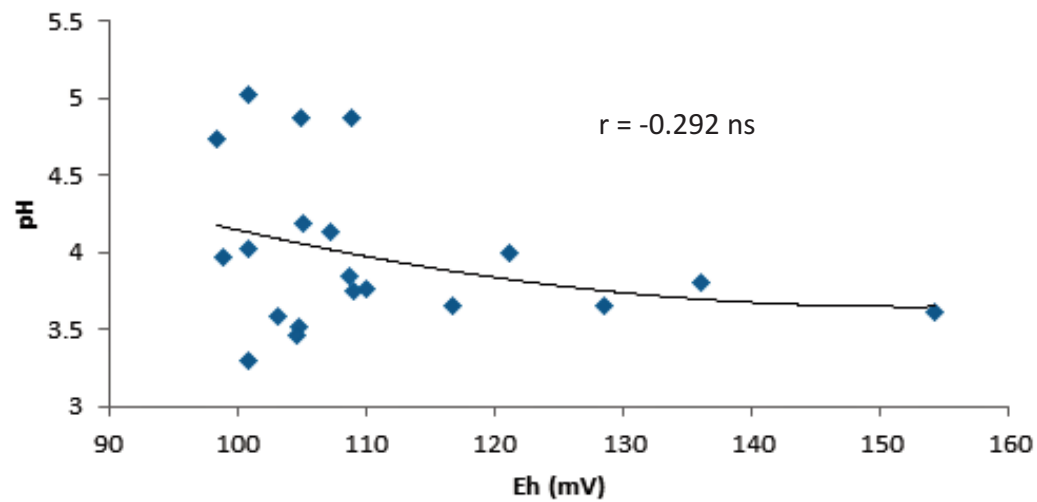

Figure 5. Relationship between $\mathrm{Eh}$ and $\mathrm{pH}$ of leachate water, and the treatment of inoculant formulas, water management and phytoremediation materials

treatment of iron oxidizing bacteria with charcoal wood increased to $276 \mathrm{ppm}$ higher than liquefied leather TDS in the treatment of iron oxidizing bacteria with charcoal husk of only $223 \mathrm{ppm}$. TDS is an indicator used to measure the high content of dissolved solids in ground water. The high value of TDS in the soil becomes an indication of the presence of fracture in the parent rock, thus causing the quality of leachate water to decrease.

\section{Relationship between Eh Value, pH and TDS of leachate to water quality}

Figure 5 and Figure 6 show the relationship between the value of $\mathrm{Eh}, \mathrm{pH}$ and TDS in leachate water. As seen in Figure 5, more oxidative environmental conditions were indicated by an increase in the value of Eh leachate water so it will be followed by a decrease in the $\mathrm{pH}$ value of the leachate water, whereas the TDS value of leachate water was directly proportional to the Eh leachate water value (Figure 6). TDS is generally caused by inorganic materials in the form of ions commonly found in waters. Changes in $\mathrm{pH}$ and Eh soil will affect the stability and solubility of metal minerals (Satawathananont et al., 1991).

\section{Relation between $\mathrm{Fe}$ and $\mathrm{SO}_{4}$ value to leachate water quality in acid sulphate soil}

Figure 7 shows that the relationship between $\mathrm{Fe}$ and $\mathrm{SO}_{4}{ }^{2-}$ was directly proportional. There was no insignificant possitive correlation between $\mathrm{Fe}$ and $\mathrm{SO}_{4}{ }^{2}$. The higher the $\mathrm{Fe}$, the more increasing the $\mathrm{SO}_{4}$ value was. This is in accordance with the research 


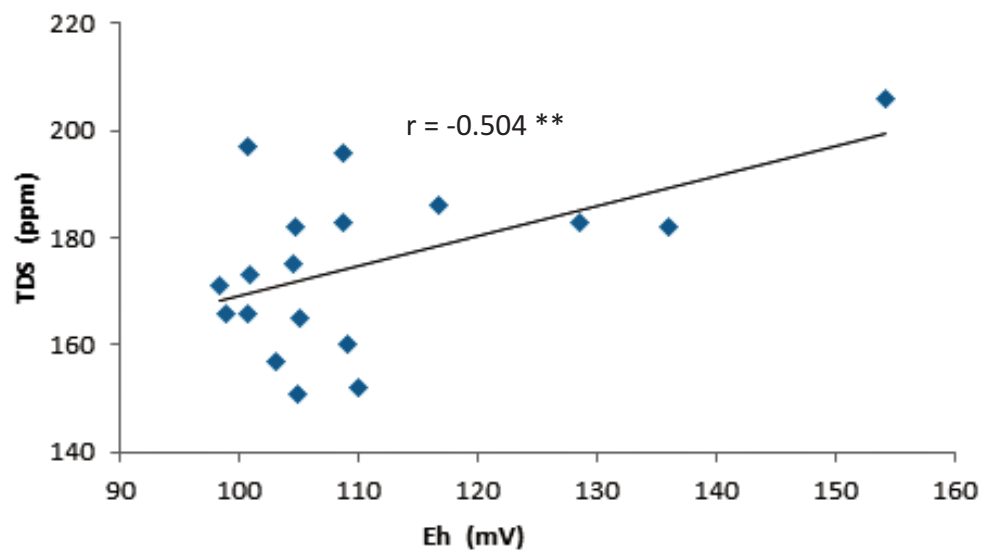

Figure 6. Relationship between Eh and TDS of leachate water, and the treatment of inoculant formulas, water management and phytoremediation materials.

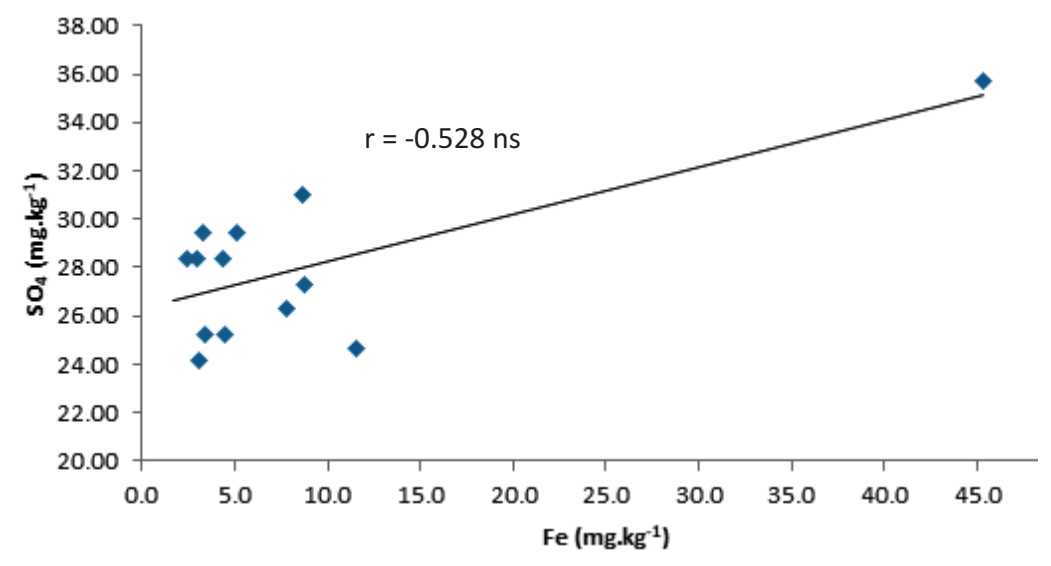

Figure 7. Relationship between water $\mathrm{Fe}$ and leachate water $\mathrm{SO}_{4}$, and the treatment of inoculant formulas, water management and phytoremediation materials.

by Yuliana (2012) highlighting that the measurement of ferri iron at the end of drying showed an increase of ferri iron from $424.73 \mathrm{ppm}$ to $448.52 \mathrm{ppm}$ and the soluble sulphate $\left(\mathrm{SO}_{4}{ }^{2-}\right)$ also increased from 348.64 to $436.18 \mathrm{ppm}$. Oxidized pyrite besides releasing $\mathrm{H}^{+}$and $\mathrm{SO}_{4}{ }^{2}$ ions also releases $\mathrm{Fe}^{3+}$. In reductive conditions, thermodynamics does not adequately explain the $\mathrm{Fe}^{3+}$ reduction because there are other non-enzymatic mechanisms associated with the $\mathrm{Fe}^{3+}$ reduction process, so in addition to the organic material, sulphate also determines the intensity of $\mathrm{Fe}^{3+}$ reduction due to the utilization of sulphate as the primary electron acceptor by microbes in the $\mathrm{Fe}^{3+}$ reduction process (Annisa, 2014).
The role of inoculant formula, water management and phytoremediation materials on rice growth in acid sulphate soil

\section{Plant growth}

In Table 2 and 3, the agronomic observations of plants showed that there was a possitive interaction among three factors on the height and the number of paddy saplings, which were in inoculant formula, water management, and phytoremediation materials. This was related to the quality of the produced leachate water. The leaching will rinse iron (Fe) in the form of $\mathrm{Fe}^{2+}$, so that soil conditions will be more suitable for development of plant root. 
Table 2. Height of rice plant $(\mathrm{cm})$ due to treatment of inoculation formula, water management and phytoremediation material in last observation (12 WAP)

\begin{tabular}{|c|c|c|c|c|c|c|c|}
\hline \multirow{2}{*}{\multicolumn{2}{|c|}{ Treatment }} & \multicolumn{5}{|c|}{ Inoculation Formula } & \multirow{2}{*}{ Average } \\
\hline & & $\mathrm{T} 1$ & $\mathrm{~T} 2$ & T3 & $\mathrm{T} 4$ & $\mathrm{~T} 5$ & \\
\hline \multirow[t]{2}{*}{ P1 } & A1 & $92.17 a b$ & $92.67 a b$ & $89.00 \mathrm{ab}$ & $89.33 a b$ & $91.67 \mathrm{ab}$ & 90.97 \\
\hline & $\mathrm{A} 2$ & $89.83 a b$ & 87.67 b & $91.67 \mathrm{ab}$ & 94.17 a & $90.67 \mathrm{ab}$ & 90.80 \\
\hline \multirow[t]{2}{*}{ P2 } & $\mathrm{A} 1$ & $89.83 a b$ & $92.67 \mathrm{ab}$ & $91.67 \mathrm{ab}$ & 95.33 a & $89.50 \mathrm{ab}$ & 91.80 \\
\hline & $\mathrm{A} 2$ & $90.67 \mathrm{ab}$ & $94.67 \mathrm{a}$ & $87.67 \mathrm{~b}$ & $91.67 \mathrm{ab}$ & $93.00 \mathrm{ab}$ & 91.54 \\
\hline & & $90.62 \mathrm{a}$ & $91.92 \mathrm{a}$ & $90.00 \mathrm{a}$ & $92.62 \mathrm{a}$ & $91.21 \mathrm{a}$ & $(+)$ \\
\hline \multicolumn{8}{|c|}{$\mathrm{CV}(\%)=3.54$} \\
\hline \multicolumn{8}{|c|}{$\begin{array}{l}\text { Remarks: T: Inoculant formula. (T1: Formulation, T2: material of wood charcoal carrier, T3: material of hus } \\
\text { charcoal, T4: Inoculant of iron oxidizing bacteria + wood charcoal, and T5: Inoculant of iron oxidizing } \\
\text { bacteria + husk charcoal). P: Water management (P1: Closed system, P2: Opened system). A } \\
\text { Phytoremediation materials (A1 : E.dulcis, A2: E. retroflaxa). The (+) indicates an interaction betweer } \\
\text { factors }\end{array}$} \\
\hline
\end{tabular}

Table 3. Number of paddy saplings due to the treatment of inoculant formula, water management and phytoremediation material in small pots in last observation

\begin{tabular}{|c|c|c|c|c|c|c|c|}
\hline \multirow{2}{*}{\multicolumn{2}{|c|}{ Treatment }} & \multicolumn{5}{|c|}{ Inoculation Formula } & \multirow{3}{*}{$\begin{array}{c}\text { Average } \\
25.07\end{array}$} \\
\hline & & \multirow{2}{*}{$\frac{\mathrm{T} 1}{25.00 \mathrm{bcde}}$} & \multirow{2}{*}{$\frac{\mathrm{T} 2}{26.33 \mathrm{abcd}}$} & \multirow{2}{*}{$\frac{\text { T3 }}{27.00 a b c}$} & \multirow{2}{*}{$\begin{array}{c}\text { T4 } \\
23.33 \mathrm{cde}\end{array}$} & \multirow{2}{*}{$\begin{array}{c}\text { T5 } \\
23.67 \mathrm{cde}\end{array}$} & \\
\hline P1 & $\mathrm{A} 1$ & & & & & & \\
\hline & $\mathrm{A} 2$ & 23.00 cde & 25.33 bcde & 24.00 cde & 24.33 bcde & 25.33 bcde & 24.40 \\
\hline \multirow[t]{2}{*}{$\mathrm{P} 2$} & $\mathrm{~A} 1$ & 25.00 bcde & $22.67 \mathrm{de}$ & 25.00 bcde & $28.00 \mathrm{ab}$ & $21.67 \mathrm{e}$ & 24.47 \\
\hline & $\mathrm{A} 2$ & $29.33 \mathrm{a}$ & $26.67 \mathrm{abcd}$ & 24.33 bcde & 25.33 bcde & 24.00 cde & 25.93 \\
\hline \multicolumn{2}{|c|}{ Average $\mathrm{T}$} & $25.58 \mathrm{a}$ & $25.25 a b$ & $25.08 a b$ & $25.25 a b$ & $23.67 b$ & $(+)$ \\
\hline \multicolumn{8}{|c|}{$\mathrm{CV}(\%)=8.09$} \\
\hline \multicolumn{8}{|c|}{$\begin{array}{l}\text { Remarks: T: Inoculant formula. (T1: Formulation, T2: material of wood charcoal carrier, T3: material of husk } \\
\text { charcoal, T4: Inoculant of iron oxidizing bacteria + wood charcoal, and T5: Inoculant of iron oxidizing } \\
\text { bacteria + husk charcoal). P: Water management (P1: Closed system, P2: Opened system). A } \\
\text { Phytoremediation materials (A1 : E.dulcis, A2: E. retroflaxa).The (+) indicates an interaction between } \\
\text { factors }\end{array}$} \\
\hline
\end{tabular}

Plant height in the inoculant treatment + wood charcoal was in the range of $89.33-95.33 \mathrm{~cm}$, while in the inoculant treatment + husk charcoal it was in the range $89.50-93.00 \mathrm{~cm}$. Meanwhile, the number of paddy saplings in the inoculant treatment + wood charcoal + inoculant + husk charcoal were in the range of 23.33-28.00 and 21.67-25.33 (Table 2 and 3) respectively. Generally they look high and the number of paddy saplings with inoculant treatment and wood charcoal were better than that in inoculant treatment and husk charcoal.

Table 4 shows a positive interaction among those three treatment factors; inoculant formula, water management and phytoremediation materials. It is seen that in the treatment of wood charcoal, the management of closed water and phytoremediation material of the E.retroflaxa was the lowest at $26.00 \mathrm{~g}$, while the treatment of inoculant formula and husk charcoal, opened water management, and photoremediation material of $E$. dulcis plant was higher equal to $32.67 \mathrm{~g}$. This was because $\mathrm{pH}$ of soil and water in pots where the rice was planted was high, so the ability of rice plant to absorb nutrients was higher. According to Masganti (2011), straw weight is an indicator of rice ability to absorb nutrients. The level of nutrient availability influenced by soil acidity is one of the determinant factors for the ability of plants to absorb nutrients (Marschner, 1986).

Figure 8 shows that the treatment with oxidizing iron bacteria inoculant + wood charcoal obtained 5.64 ton. ha ${ }^{-1}$ which was higher than that of inoculant treatment of iron oxidation bacteria + husk charcoal which was only 5.11 ton.ha-1 ${ }^{-1}$ This was supported by 
Table 4. Trubus weight of rice plant (g) by treatment of inoculant formula, water management and phytoremediation materials

\begin{tabular}{|c|c|c|c|c|c|c|c|}
\hline \multirow{2}{*}{\multicolumn{2}{|c|}{ Treatment }} & \multicolumn{5}{|c|}{ Inoculation Formula } & \multirow{3}{*}{$\begin{array}{l}\text { Average } \\
28.30\end{array}$} \\
\hline & & \multirow{2}{*}{$\begin{array}{c}\mathrm{T} 1 \\
29.50 \mathrm{abcd}\end{array}$} & \multirow{2}{*}{$\begin{array}{c}\mathrm{T} 2 \\
31.50 \mathrm{abc}\end{array}$} & \multirow{2}{*}{$\frac{\mathrm{T} 3}{28.00 \mathrm{abcd}}$} & \multirow{2}{*}{$\frac{T 4}{25.50 d}$} & \multirow{2}{*}{$\frac{\text { T5 }}{27.00 \mathrm{bcd}}$} & \\
\hline $\mathrm{P} 1$ & A1 & & & & & & \\
\hline & $\mathrm{A} 2$ & $28.00 \mathrm{abcd}$ & $26.00 \mathrm{~cd}$ & $27.50 \mathrm{abcd}$ & $27.50 \mathrm{abcd}$ & $26.83 \mathrm{bcd}$ & 27.17 \\
\hline \multirow[t]{2}{*}{$\mathrm{P} 2$} & $\mathrm{~A} 1$ & $26.83 \mathrm{bcd}$ & $26.00 \mathrm{~cd}$ & $28.00 \mathrm{abcd}$ & $32.17 a b$ & $32.67 \mathrm{a}$ & 29.13 \\
\hline & $\mathrm{A} 2$ & $31.00 \mathrm{abcd}$ & $31.67 \mathrm{ab}$ & $29.00 \mathrm{abcd}$ & $30.00 \mathrm{abcd}$ & $28.33 \mathrm{abcd}$ & 30.00 \\
\hline \multicolumn{2}{|c|}{ Average $\mathrm{T}$} & $28.83 \mathrm{a}$ & $28.79 \mathrm{a}$ & $28.12 \mathrm{a}$ & 28.79 a & $28.71 \mathrm{a}$ & $(+)$ \\
\hline \multicolumn{2}{|c|}{ Average $\mathrm{P}$} & $P 1=27.73 b$ & & $\mathrm{P} 2=29.57 \mathrm{a}$ & & & \\
\hline \multicolumn{2}{|c|}{ Average A } & $\mathrm{A} 1=28.72 \mathrm{a}$ & & $A 2=28.58 a$ & & & \\
\hline
\end{tabular}

Remarks: T: Inoculant formula. (T1: Formulation, T2: material of wood charcoal carrier, T3: material of husk charcoal, T4: Inoculant of iron oxidizing bacteria + wood charcoal, and T5: Inoculant of iron oxidizing bacteria + husk charcoal). P: Water management (P1: Closed system, P2: Opened system). A: Phytoremediation materials (A1: E. dulcis, A2: E. retroflaxa). The (+) indicates an interaction between factors

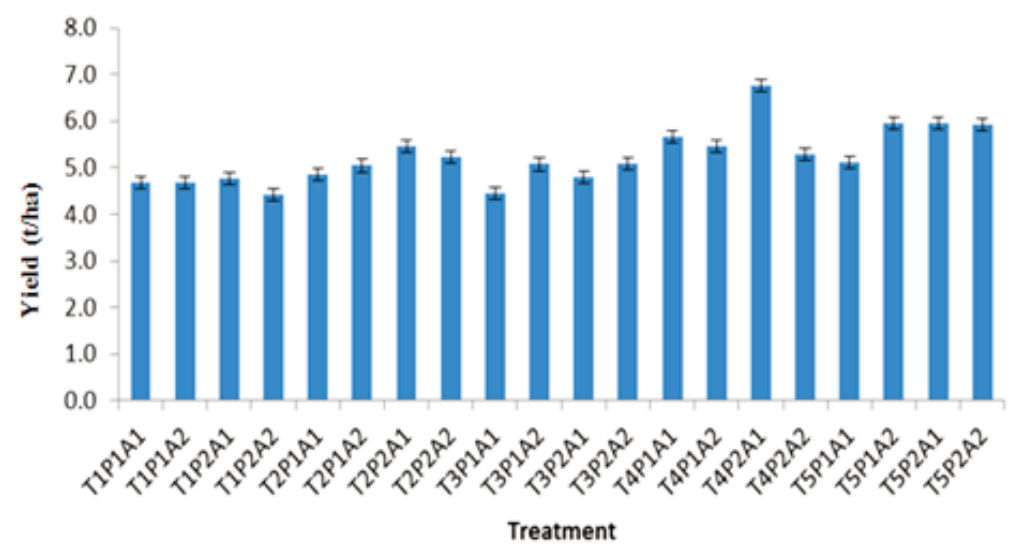

Figure 8. Rice yield with the treatment of inoculant formulas, water management and phytoremediation materials

the high $\mathrm{pH}$ of leachate water when approaching harvest (12 WAP). It was seen that $\mathrm{pH}$ at the inoculant treatment of oxidizing iron bacteria + wood charcoal was 5.02 (Figure 2). Soil acidity (pH) may affect soil nutrient availability and may be a factor related to soil quality and limiting factors to plant growth and production (Aksani, 2016). The high value of TDS in the inoculant of iron oxidizing bacteria with wood charcoal was also influential due to the availability of dissolved solid elements in leachate water. This was related to the $\mathrm{pH}$ of leachate water where the increased $\mathrm{pH}$ water can affect the availability of soluble nutrients easily in water (Sulistiyani et al., 2014). Application of the pyrite oxidizing bacterial and leaching eight times gave the best influence on the growth and yields of rice plants (Maftuah and Susilawati, 2018).

\section{CONCLUSIONS}

The inoculant treatment of iron oxidizing bacteria with charcoal carrier material can improve the water quality. Fe concentration with inoculant treatment of iron oxidizing bacteria + husk charcoal was only 9.750 mg. kg-1 which was lower than inoculant treatment of oxidizing bacteria of iron + wood charcoal with 10.060 mg. $\mathrm{kg}^{-1}$. The highest grain yield in the treatment of iron oxidizing bacteria inoculant + wood charcoal was higher, which was 6.77 ton.ha-1 ${ }^{-1}$

\section{ACKNOWLEDGMENTS}

We are deeply indebted to members of Laboratory of Indonesian Swampland Agricultural Research Institute for their help during laboratory works. 


\section{REFERENCES}

Aksani, D. 2016. Peningkatan $\mathrm{pH}$ tanah pada budidaya padi lahan pasang surut melalui aplikasi pupuk cair dari neptunia prostrata. Prosiding Seminar Nasional Lahan Suboptimal. 584-591.

Alia, O., M. Laila, and A. Antonius. 2013. Antimicrobial effect of melittin isolated from syrian oneybee (Apis mellifera) venom and its wound healing potential. Int J. Pharm. Sci. Rev. Res., 21: 318324.

Annisa, W. 2014. Peran bahan organik dan tata air mikro terhadap kelarutan besi, emisi $\mathrm{CH}_{4}$, emisi $\mathrm{CO}_{2}$ dan produktivitas padi di lahan sulfat masam. Universitas Gadjah Mada, Yogyakarta, 66-67. (Dissertation)

Asikin, A. and M. Thamrin. 2012. Manfaat purun tikus (Eleocharis dulcis) pada ekosistem rawa. Jurnal Litbang Pertanian., 31: 35 - 42.

Bacelor-Nicolau, P., and D. B. Johnson. 1999. Lounching of piryte by acidophillie iron oxidating-bacteria. J. Apple/Env. Microbial., 65: 585-590.

Balai Penelitian dan Pengembangan Pertanian. 2013. Lahan rawa. $2^{\text {nd }}$ ed., Jakarta: IAARD Press, Badan Penelitian dan Pengembangan Pertanian, Kementerian Pertanian.

Balai Penelitian Tanah. 2012. Analisis kimia tanah, tanaman, air, dan pupuk. $2^{\text {nd }}$ ed., Bogor: Balai Penelitian Tanah.

Becker, M. and F. Ash. 2005. Iron toxicity in rice condition and management concept. Journal of Plant Nutrition and Soil Science., 168 : 558-573.

Haynes, R.J. and M.S. Mokolobate. 2001. Amelioration of $\mathrm{Al}$ toxicity and $\mathrm{P}$ deficiency in acid soil by additions of organic residues: A critical review of the phenomenon and the mechanisms involved. Nutrient Cycling In Argoecosystems., 59: 47-63.

Hazra, F. and E. Widyati, 2007. Isolasi, seleksi bahan pembawa dan formulasi inokulan Thiobacillus spp. Jurnal Tanah dan Lingkungan., 9:71-76.
Jumberi, A.; M. Syarwani and Koesrini. 2004. Komponen teknologi pengelolaan lahan dan tanaman untuk meningkatkan produktifitas dan efisiesi produksi di lahan sulfat masam. p. 9-14. In: T. Alihamsyah and N. Izzuddin. Laporan Tahunan 2003. Banjarbaru : Balai Penelitian Pertanian Lahan Rawa.

Lu, H.L., C.R. Ku., and Y.H. Chang. 2015. Water quality improvement with artificial floating islands. Journal Ecological Engineering., 75: 371-375.

Maftuah, E., and A. Susilawati. 2018. Bioleaching untuk meningkatkan produktivitas lahan sulfat masam aktual untuk tanaman padi. Jurnal IImu-IImu Hayati., 17: 253-264.

Mariana, Z.T., F. Razie, and M. Septiana. 2012. Populasi bakteri pengoksidasi besi dan sulfur akibat penggenangan dan pengeringan pada tanah sulfat masam di Kalimantan Selatan. Jurnal Agroscientiec., 19: 22-27.

Marschner, H. 1986. Mineral nutrion of higher plants. $2^{\text {nd }}$ ed., London:Academic Press Inc., London.

Masganti. 2011. Perbedaan daya serap hara beberapa varietas unggul padi pada tipe lahan berbeda di lahan pasang surut. Jurnal Penelitian Pertanian Tanaman Pangan., 30:23-29.

Napisah, K. and W. Annisa. 2019. Peran purun tikus (Eleocharis dulcis) sebagai penyerap dan penetral Fe di lahan rawa pasang surut. Jurnal Sumberdaya Lahan., 13: 53-59.

Notohadiprawiro, T. 2000. Tanah dan lingkungan. $2^{\text {nd }}$ ed., Yogyakarta: Gadjah Mada University Press.

Nurseha and Djajakirana G. 2004. Isolasi dan uji aktivitas bakteri asidofilik pengoksidasi besi dan sulfur dari ekosistem air hitam di Kalimantan Tengah. Jurnal Tanah dan Lingkungan., 6: 51-56.

Ponnamperuma. 1977. Behavior of minor elements in paddy soils. $8^{\text {th }}$ ed., Manila: International Research Institute, Philippines.

Pusparani, S. 2018. Characterization of soil physic and chemistry properties of mineral acidic sulphate soil on tidal land. Jurnal Hexagro, 2: 1-4.

Satawathananont, W.H. Patrick, and P.A. Moore. 
1991. Effect of controlled redox conditions on metal solubility in acid sulphate soil. J. Plant and Soil, 133: 281-290.

Su, J.Q., Y. Xia, H.Y. Yao, Y.Y. Li, X.L. An; B.K. Singh, T. Zhang, and Y.G. Zhu. 2017. Metagenomic assembly unravel microbial response to redox fluctuation in acid sulfate soil. Journal Soil Biology and Biochemistry, 105: 244-252.

Susilawati, A. and A. Fahmi., 2013. Dinamika besi pada tanah sulfat masam yang ditanami padi. Jurnal Sumberdaya Lahan, 7: 67-75.
Sulistiyani, D.P., Napolean, and A.G. Putra. 2014. Penilaian kualitas tanah pada lahan rawa pasang surut untuk tanaman jagung (Zea mays L.) di Desa Banyu Urip Kecamatan Tanjung Lago Kabupaten Banyuasin. Prosiding Seminar Nasional Lahan Suboptimal. 812-820.

Yuliana, E.D. 2012. Jenis mineral liat dan perubahan sifat kimia tanah akibat proses reduksi dan oksidasi pada lingkungan tanah sulfat masam. Jurnal Bumi Lestari, 12:327-337. 